\title{
Perancangan Assesmen Literasi Kimia Pada Materi Laju Reaksi Kelas XI SMA/MA
}

\section{Design of Chemical Literacy Assessment} on Reaction Rate Topic of $11^{\text {th }}$ Grade Senior High School

\author{
C M Pakesa ${ }^{1}$ and E Yusmaita ${ }^{1^{*}}$ \\ ${ }^{1}$ Pendidikan Kimia, Universitas Negeri Padang, Jl. Prof. Dr. Hamka, Air Tawar Barat, \\ Padang Utara, Sumatera Barat, Indonesia 25171 \\ *ekayusmaita@fmipa.unp.ac.id
}

\section{ARTICLE INFO}

Received 11 October 2019

Revised 20 October 2019

Published 21 October 2019

\section{ABSTRACT}

This research aims to produce instruments for measure chemical literacy assessment in senior high school with theme the reaction rate. This chemical literacy assessment designed by MER (Model of Educational Reconstruction). MER consists of 3 components are (1) analysis of science content, (2) study empiric, (3) construction assessment chemistry literacy. This research is limited to the study empiric. The validity of the chemical literacy assessment content carried out by 2 chemistry lecturers from FMIPA UNP and 1 chemistry teacher in Padang. The content validity instruments analysed using the Aiken V. The analysis shows that 9 of 13 questions in category "valid", 4 questions in category "moderate". Overall analysis results the validity of content designed "valid" with a value of 0.85 .

\section{KEYWORDS}

Assessment, Chemistry literacy, reaction rate, Model of Educational Reconstruction, Aiken V.

\section{ABSTRAK}

Tujuan dari penelitian ini yaitu membuat intrumen untuk mengukur penilaian literasi kimia di sekolah menengah atas pada materi laju reaksi.Assesmen literasi kimia ini dirancang menggunakan desain MER (Model of Educational Reconstruction). MER terdiri dari 3 komponen yaitu (1) analisis konten sains, (2) penyelidikan empiris, (3) konstruksi assesmen literasi kimia.Pada penelitian ini dibatasi sampai tahapan penyelidikan empiris.Validitas konten assesmen literasi kimia ini dilakukan oleh 2 orang dosen kimia FMIPA UNP dan 1 orang guru kimia di kota Padang. Intrumen validitas konten dianalisis menggunakan rumus Aiken V. Hasil analisis menunjukkan bahwa 9 dari 13 soal dalam kategori "valid”, 4 soal dalam kategori "sedang”. Secara keseluruhan hasil analisis menunjukkan bahwa validitas konten assesmen yang dirancang "valid" dengan nilai 0,85 .

\section{KATA KUNCI}

Assesmen, Literasi kimia, Laju Reaksi, Model of Educational Reconstruction, Aiken V. 


\section{PENDAHULUAN}

Penilaian adalah proses pengumpulan dan pengolahan informasi untuk mengukur pencapaian hasil belajar peserta $\operatorname{didik}^{[1]}$. Asesmen (penilaian) dapat diartikan sebagai suatu proses pengumpulan data dan/atau informasi (termasuk di dalamnya pengolahan dan pendokumentasian) secara sistematis tentang suatu atribut, orang atau objek, baik berupa data kualitatif maupun kuantitatif tentang jumlah, keadaan, kemampuan atau kemajuan suatu atribut, objek atau orang/individu yang dinilai, tanpa merujuk pada keputusan nilai ${ }^{[2]}$.

Salah satu bentuk penilaian pendidikan secara international dilakukan oleh lembaga OECD (Organization for Economic Co-operation and Development) dengan salah satu programnya yaitu PISA. PISA ialah singkatan dari Programme for International Student Assessment. Subjek penilaian dari PISA ini salah satunya adalah literasi sains. Literasi sains didefinisikan sebagai kemampuan menggunakan pengetahuan sains, mengidentifikasi pertanyaan, dan menarik kesimpulan berdasarkan bukti-bukti, dalam rangka memahami serta membuat keputusan berkenaan dengan alam dan perubahan yang dilakukan terhadap alam melalui aktivitas manusia ${ }^{[3]}$. Literasi sains merupakan suatu hal yang penting karena literasi sains dapat membantu siswa kedepannya dalam mengatasi permasalahan yang berkaitan dengan pengetahuan dan teknologi yang semakin kompleks ${ }^{[4]}$.

Penelitian yang dilakukan oleh Haristy (2013) tentang pembelajaran berbasis literasi sains pada materi larutan elektrolit dan non elektrolit, dimana pembelajaran literasi sains dapat membuat siswa menjadi lebih aktif dan termotivasi dalam memfokuskan atau mengarahkan pikiran dalam belajar. Selain itu juga dalam pembelajaran tersebut, dapat membuat siswa belajar dengan cara menemukan dan melatih siswa untuk lebih kritis dalam berpikir ilmiah serta mengaitkannya dalam kehidupan sehari-hari ${ }^{[5]}$.

Penelitian yang dilakukan oleh Prastiwi (2017) tentang studi kemampuan literasi kimia peserta didik pada materi elektrokimia. Dari hasil penelitian tersebut, berdasarkan hasil wawancara kepada guru, rendahnya kemampuan literasi kimia peserta didik didukung oleh beberapa faktor, diantaranya adalah pada kegiatan evaluasi diakhir materi, dimana guru cenderung lebih tertarik membuat soal uraian sederhana. Soal yang dibuat belum memuat aspek literasi kimia, karena membuat soal yang memuat aspek literasi kimia dianggap masih sulit. Artinya, hanya beberapa topik pembelajaran yang dikembangkan menjadi soal yang dianggap mampu digunakan untuk mengukur literasi kimia. Selain itu, guru cenderung lebih sering membuat soal hitungan. Hal ini menyebabkan peserta didik hanya dapat mengembangkan kemampuan matematis saja $^{[6]}$.

Oleh sebab itu, diperlukanlah suatu assesmen terutama assesmen literasi kimia. Hal ini dilakukan agar peserta didik dapat melek literasi terutama dibidang kimia. Dengan terciptanya assesmen literasi kimia yang valid dan reliabel diharapkan mampu memberikan gambaran bagaimana kemampuan literasi peserta didik dalam menjawab soal.

Perancangan assemen literasi kimia ini disusun berdasarkan aspek konten, konteks, keterampilan belajar tingkat tinggi serta sikap berdasarkan domain literasi kimia yang dibuat oleh Shwartz dan rubrik penilaian berdasarkan tingkat level literasi sains yang dikemukakan oleh Bybee ${ }^{[7]}$ yaitu Scientific illiteracy, Nominal scientific literacy, Functional scientific literacy, Conceptual scientific literacy, Multidimensional scientific literacy.

\section{METODE}

Jenis penelitian ini yaitu penelitian pengembangan dengan desain MER (Model of Educational Reconstruction).Yang bertujuan untuk mengembangkan assesmen literasi kimia pada materi laju reaksi. Subjek penelitian ini adalah 2 orang dosen kimia FMIPA UNP dan 1 orang guru kimia SMA. Objek penelitian ini adalah instrument assesmen literasi kimia pada materi laju reaksi.

Untuk analisis data validasi konten menggunakan rumus Aiken V. Rumus Aiken V sebagai berikut

$$
\begin{gathered}
\mathrm{V}=\sum \mathrm{s} /[\mathrm{n}(\mathrm{c}-1)] \\
\mathrm{s}=\mathrm{r}-\mathrm{lo}
\end{gathered}
$$

lo = Angka penilaian validitas yang terendah (dalam hal ini $=1$ )

$\mathrm{c}=$ Angka penilaian validitas yang tertinggi $($ dalam hal ini $=5)$

$\mathrm{r}=$ Angka yang diberikan oleh seorang penila $\mathrm{i}^{[8]}$.

Adapun kriteria penilaian validitas berdasarkan skala Aiken V dapat dilihat pada Tabel 1.

Tabel 1. Validitas Berdasarkan Skala Aiken V ${ }^{[9]}$

\begin{tabular}{c|c|c} 
No & Skala Aiken V & Validitas \\
\hline 1 & $\mathrm{~V} \leqslant 0,4$ & Kurang \\
\hline 2 & $0,4<\mathrm{V} \leqslant 0,8$ & Sedang \\
\hline 3 & $0,8<\mathrm{V}$ & Valid
\end{tabular}

Desain pengembangan yang digunakan pada penelitian ini yaitu MER. MER merupakan singkatan dari Model of Educational Reconstruction. Model MER ini dikembangkan oleh Reinders Duit, Harald Gropengiesser, Ulrich Kattman dan Michael Komorek sejak tahun 1995 sampai sekarang. Tujuan perancangan MER yaitu sebagai kerangka penelitian dan pengembangan pendidikan sains ${ }^{[10]}$. MER terdiri dari 3 komponen yaitu: (1) Klarifikasi dan analisis konten sains, (2) Penelitian mengajar dan belajar, (3) Pengembangan dan evaluasi pembelajaran. Untuk lebih jelasnya, perhatikan Gambar 1 berikut ini: 


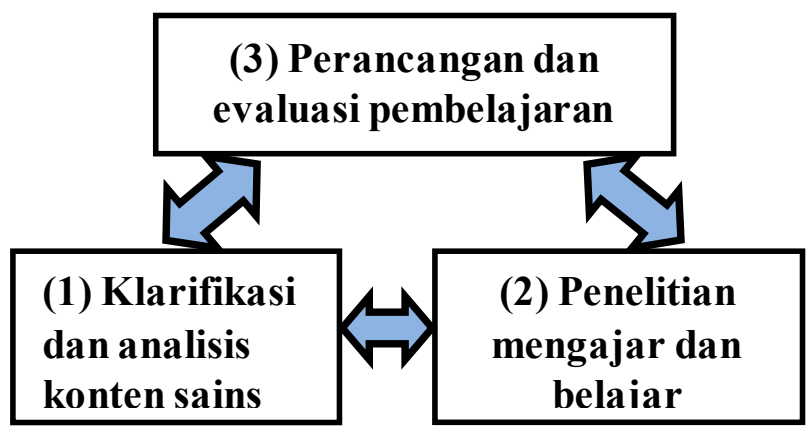

Gambar 1. Tiga Komponen MER (Model of Educational Reconstruction)

Komponen yang pertama adalah klarifikasi dan analisis konten sains. Tujuan dari komponen tersebut adalah untuk mengklarifikasi konsepsi sains yang spesifik dan stuktur konten dari sudut pandang pendidikan. Komponen kedua adalah penelitian mengajar dan belajar mengidentifikasi bahwa proses klarifikasi dan analisis dari konten sains pada satu sisi dan proses konstruksi terhadap struktur konten untuk pengajaran pada sisi yang lain membutuhkan dasar penelitian empiris pada mengajar dan belajar. Studi empiris terhadap pengaturan belajar tertentu membutuhkan studi lebih lanjut dengan melakukan investigasi konsepsi siswa dan variable afektif seperti ketertarikan, konsep diri dan sikap. Komponen ketiga adalah perancangan dan evaluasi pembelajaran. Komponen ini terdiri dari merancang soal sesuai konstruksi yang diinginkan ${ }^{[10]}$.

Secara keseluruhan kontribusi terhadap MER dapat dilihat dalam menyiapkan kerangka komponen sains yang relevan terhadap penelitian pendidikan sains dan pengembangannya serta dengan cara demikian membentuk hubungan trilateral. Pada pelaksanaanya, semua tahapan pada komponen pertama model ini tidak mutlak harus diselesaikan terlebih dahulu. Proses penelitiannya dapat bersifat bolak-balik (recursive) sehingga dalam melakukan penyempurnaan komponen pertama dipengaruhi juga oleh komponen kedua dan ketiga. Komponen pertama, kedua, maupun ketiga dilakukan secara berselang-seling sesuai dengan tujuan dan kepentingan penelitian yang akan dicapai ${ }^{[11]}$.

\section{HASIL DAN DISKUSI}

Selama proses pelaksanaan penelitian ini, tiga komponen dasar MER tersebut dimodifikasi menjadi skema baru. Berikut skema desain perancangan assesmen literasi kimia pada materi laju reaksi dalam bentuk Gambar 2.

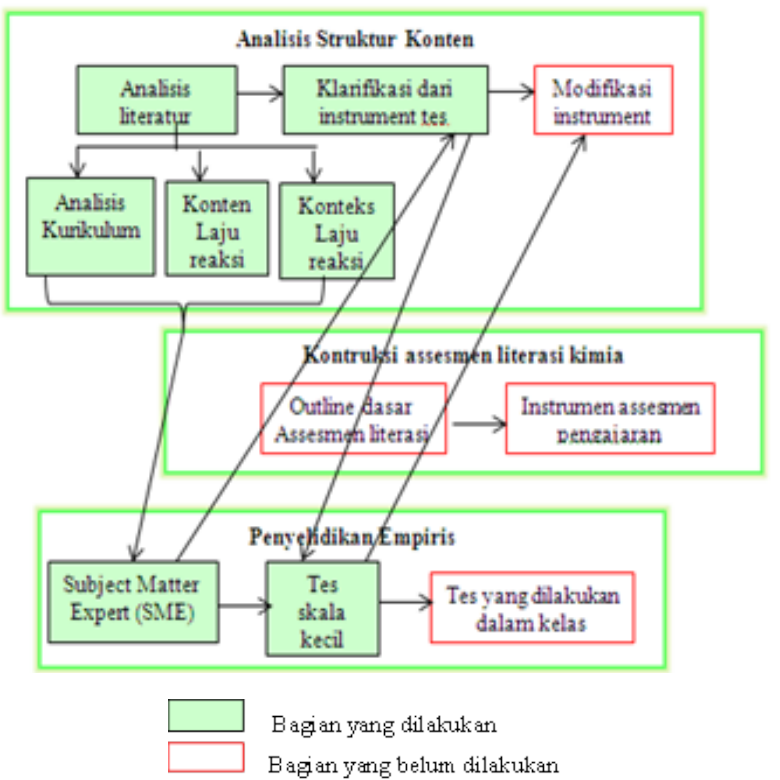

Gambar 2. Skema Bagan MER yang dimodifikasi

\subsection{Analisis struktur konten}

Komponen pertama dari yaitu analisis literatur. Tahapan yang dilakukan pada analisis ini yaitu: analisis kompetensi dasar pada mata pelajaran kimia SMA yaitu materi laju reaksi. Laju reaksi merupakan salah satu materi pelajaran kimia di SMA/MA kelas XI semester ganjil. Berdasarkan kurikulum 2013 Kompetensi Dasar (KD) pada pokok bahasan laju reaksi yaitu sebagai berikut:

\section{Kompetensi Dasar:}

3.6 Menjelaskan faktor - faktor yang mempengaruhi laju reaksi menggunakan teori tumbukan

Untuk melihat ketercapaian kompetensi dasar yang akan dicapai siswa, maka indikator pencapaian kompetensi (IPK) adalah

Indikator Pencapaian Kompetensi:

3.6.1 Menjelaskan konsep laju reaksi berdasarkan contoh yang diberikan

3.6.2 Menjelaskan tentang pengaruh konsentrasi terhadap laju reaksi menggunakan teori tumbukan

3.6.3 Menjelaskan tentang pengaruh luas permukaan terhadap laju reaksi menggunakan teori tumbukan tentang pengaruh suhu terhadap laju reaksi menggunakan teori tumbukan

3.6.5 Menjelaskan tentang pengaruh katalis terhadap laju reaksi menggunakan teori tumbukan

\section{Kompetensi Dasar:}

4.6 Menyajikan hasil penelusuran informasi cara - cara pengaturan dan penyimpanan bahan untuk mencegah perubahan fisika dan kimia yang tak terkendali 
Untuk melihat ketercapaian kompetensi dasar yang akan dicapai siswa, maka IPK adalah

IPK:

4.6.1 Menjelaskan cara untuk mencegah perubahan kimia yang tak terkendali

4.6.2 Menjelaskan cara penyimpanan bahan untuk mencegah perubahan fisika

\section{Kompetensi Dasar:}

3.7 Menentukan orde reaksi dan tetapan laju reaksi berdasarkan data hasil percobaan

Untuk melihat ketercapaian kompetensi dasar yang akan dicapai siswa, maka IPK adalah

3.7.1 Menentukan orde reaksi berdasarkan data percobaan

3.7.2 Menentukan persamaan laju reaksi berdasarkan data percobaan

3.7.3 Menghitung tetapan laju reaksi berdasarkan data percobaan

Pada tahapan selanjutnya setelah melakukan analisis literatur perlu adanya tahapan klarifikasi struktur konten pada materi laju reaksi ini mengacu pada buku teks universitas yang sudah standar. Tahap selanjutnya yaitu pembuatan kisi - kisi soal literasi kimia. Adapun komponen-komponen yang terdapat pada kisi-kisi tersebut adalah KD, IPK, indikator soal, level kognitif dan level pengetahuan berdasarkan taksonomi bloom, aspek literasi kimia yang terdiri dari konteks, konten, High Order Learning Skills \& sikap, bentuk soal (essay) serta nomor soal. Pada pembuatan Indikator soal dimana disesuaikan dengan IPK.

Kemudian pembuatan kartu soal dan rubrik penilaian literasi kimia pada materi laju reaksi. Adapun pada kartu soal yang dirancang terdiri dari beberapa komponen yaitu KD, IPK, materi, indikator soal, level kognitif dan level pengetahuan serta level literasi kimia, soal literasi kimia dan jawaban soal level literasi kimia.

Berikut salah satu contoh dari soal literasi kimia yang dibuat:

Soal Nomor 4:

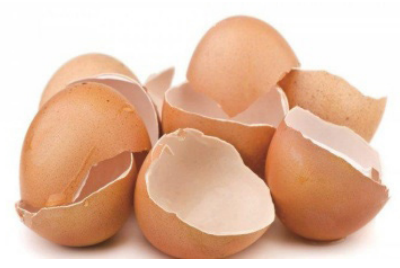

Gambar 3. Cangkang telur

Cangkang telur adalah lapisan terluar dari telur yang berfungsi melindungi semua bagian telur dari kerusakan. Komponen utama yang terdapat pada cangkang telur yaitu kalsium karbonat $\left(\mathrm{CaCO}_{3}\right)$. Penggunaan kalsium karbonat dalam bidang farmasi adalah sebagai antasida. Antasida adalah obat maag yang digunakan untuk menetralkan asam lambung. Namun kalsium karbonat dapat menyebabkan sembelit (konstipasi). Selain sebagai antasida, dalam bidang farmasi, kalsium karbonat digunakan sebagai suplemen kalsium untuk mencegah osteoporosis. Osteoporosis adalah kondisi saat kualitas kepadatan tulang menurun.Selain itu, karena cangkang telur mengandung kalsium karbonat $\left(\mathrm{CaCO}_{3}\right)$, sehingga bisa juga dimanfaatkan sebagai salah satu bahan untuk melakukan percobaan kimia. Kalsium karbonat $\left(\mathrm{CaCO}_{3}\right)$ dapat direaksikan dengan Asam cuka $\left(\mathrm{CH}_{3} \mathrm{COOH}\right)$.

Reaksi antara $\mathrm{CaCO}_{3}(\mathrm{~s})$ dengan $\mathrm{CH}_{3} \mathrm{COOH}(\mathrm{aq})$ :

$$
\begin{gathered}
\mathrm{CaCO}_{3}(\mathrm{~s})+2 \mathrm{CH}_{3} \mathrm{COOH}(\mathrm{aq}) \rightarrow \mathrm{Ca}(\mathrm{CH} 3 \mathrm{COO})_{2}(\mathrm{aq}) \\
+\mathrm{H}_{2} \mathrm{O}(\mathrm{l})+\mathrm{CO}_{2}(\mathrm{~g})
\end{gathered}
$$

Perhatikan Gambar 4. Reaksi antara $\mathrm{CaCO}_{3}(\mathrm{~s})$ dengan $\mathrm{CH}_{3} \mathrm{COOH}(\mathrm{aq})$ !

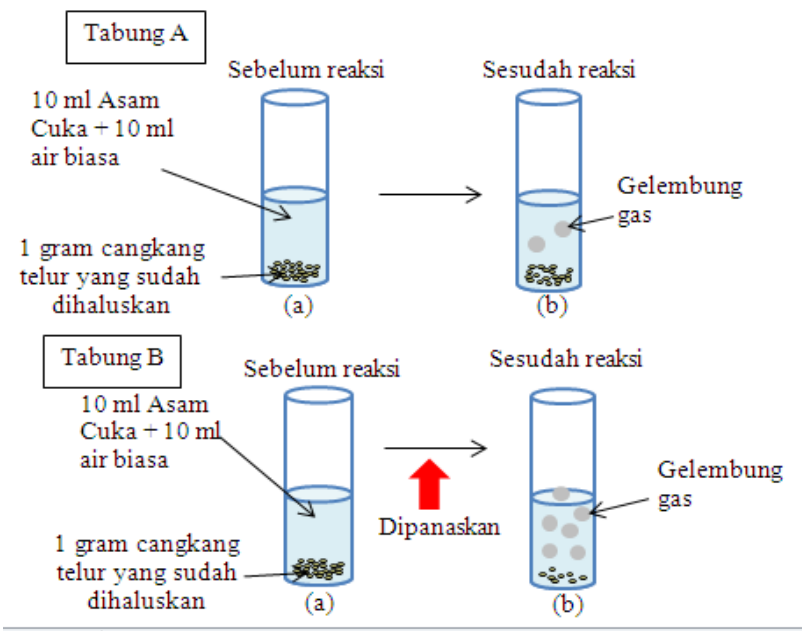

Gambar 4. Reaksi antara $\mathrm{CaCO}_{3}(\mathrm{~s})$ dengan $\mathrm{CH}_{3} \mathrm{COOH}(\mathrm{aq})$

Pertanyaan:

a. Tabung manakah yang lebih cepat bereaksi berdasarkan Gambar 4 di atas?

b. Kenapa pada suhu tinggi laju reaksi berlangsung lebih cepat? Hubungkan jawaban anda dengan teori tumbukan!

Untuk jawaban soal literasi kimia dibuat berdasarkan level literasi yaitu Scientific illiteracy: dimana siswa tidak dapat menjawab soal atau jawaban yang diberikan salah, Nominal scientific literacy: siswa menjawab secara singkat, Functional scientific literacy: siswa menjawab tetapi masih terbatas, Conceptual scientific literacy: siswa menjawab dengan baik, dimana sudah bisa menghubungkan dengan konsep yang dipelajarinya. dan Multidimensional scientific literacy: siswa mampu menjawab lebih luas lagi dengan menguhungkan dengan pemahaman ilmu lainnya. Tidak menutup kemungkinan juga salah satu bagian soal mengukur level literasi kimia pada Nominal scientific literacy dikarenakan siswa hanya dituntut menjawab jawaban yang singkat.

\subsection{Penyelidikan Empiris}

Penyelidikan empiris dilakukan kelapangan dimaksudkan agar rancangan assesmen yang 
dilakukan sesuai dengan kriteria yang semestinya. Sebelum assesmen literasi kimia diujicobakan, terlebih dahulu dilakukan pengujian validitas yaitu validitas konten (isi) oleh judgments expert. Uji validitas dilakukan oleh 3 orang validator yang merupakan Subject Matter Expert (SME) yang terdiri dari 2 orang dosen kimia FMIPA UNP dan 1 orang guru kimia di kota Padang. Uji validitas konten ini dilakukan dengan cara memberikan kisi-kisi soal literasi kimia, soal literasi kimia dan intrument penilaian kepada judgement expert.

Instrumen pengumpulan data uji validitas konten yaitu berupa angket. Pengolahan data untuk validitas konten dianalisis dengan menggunakan rumus Aiken V. Angket validitas konten disusun dengan 3 komponen yang terdiri dari wacana, pertanyaan dan jawaban soal. Untuk penilaian dari 3 komponen tersebut diberi skor 1-5. Skor terendah yaitu 1 dengan kategori sangat tidak relevan dan skor tertinggi yaitu 5 dengan kategori sangat relevan.

Hasil analisis data validitas konten assesmen literasi kimia oleh tiga judgment expert dapat dilihat pada Gambar 5 berikut:

\begin{tabular}{cccccccc}
\hline $\begin{array}{c}\text { Soal } \\
\text { Nomor }\end{array}$ & \multicolumn{2}{c}{ Judgment Expert } & & $\sum s$ & [n(c-1)] & V & Kategori \\
\cline { 2 - 5 } & $\mathrm{S}_{\mathrm{I}}$ & $\mathrm{S}_{\mathrm{II}}$ & $\mathrm{S}_{\mathrm{III}}$ & & & & \\
\hline $\mathbf{1}$ & 4.00 & 3.67 & 3 & 10.67 & 12 & 0.89 & Valid \\
$\mathbf{2}$ & 3.00 & 3.67 & 2 & 8.67 & 12 & 0.72 & Sedang \\
$\mathbf{3}$ & 3.00 & 3.67 & 4 & 10.67 & 12 & 0.89 & Valid \\
$\mathbf{4}$ & 3.00 & 3.33 & 3 & 9.33 & 12 & 0.78 & Sedang \\
$\mathbf{5}$ & 2.67 & 3.67 & 3 & 9.33 & 12 & 0.78 & Sedang \\
$\mathbf{6}$ & 4.00 & 3.33 & 3 & 10.33 & 12 & 0.86 & Valid \\
$\mathbf{7}$ & 3.33 & 3.67 & 3 & 10.00 & 12 & 0.83 & Valid \\
$\mathbf{8}$ & 3.33 & 3.67 & 4 & 11.00 & 12 & 0.92 & Valid \\
$\mathbf{9}$ & 4.00 & 3.33 & 4 & 11.33 & 12 & 0.94 & Valid \\
$\mathbf{1 0}$ & 3.33 & 4.00 & 4 & 11.33 & 12 & 0.94 & Valid \\
$\mathbf{1 1}$ & 3.33 & 3.67 & 2 & 9.00 & 12 & 0.75 & Sedang \\
$\mathbf{1 2}$ & 3.33 & 4.00 & 3 & 10.33 & 12 & 0.86 & Valid \\
$\mathbf{1 3}$ & 3.67 & 3.67 & 4 & 11.33 & 12 & 0.94 & Valid \\
\hline Rata- & $\mathbf{3 . 3 8}$ & $\mathbf{3 . 6 4}$ & $\mathbf{3 . 2 3}$ & $\mathbf{1 0 . 2 6}$ & $\mathbf{1 2}$ & $\mathbf{0 . 8 5}$ & Valid \\
rata & & & & & & & \\
\hline
\end{tabular}

Gambar 5. Hasil Analisis Data Validitas Konten (isi)

Validitas isi menunjukkan sejauh mana pertanyaan, tugas atau butir dalam suatu tes atau instrumen mampu mewakili secara keseluruhan dan proporsional perilaku sampel yang dikenai tes tersebut. Artinya tes itu valid apabila butir-butir tes itu mencerminkan keseluruhan konten atau materi yang diujikan atau yang seharusnya dikuasai secara proporsional ${ }^{[12]}$. Berdasarkan Gambar 5 di atas bahwa, 9 dari 13 soal yang dibuat berkategori "valid" dan ada beberapa soal berkategori "sedang" yaitu pada soal nomor 2, 4, 5 dan 11. Walaupun dalam kategori "sedang" soal tersebut masih bisa digunakan untuk diujicobakan kepada siswa. Sedangkan jika terdapat soal dalam kategori validitas "kurang", maka soal tersebut tidak bisa digunakan kepada siswa dan perlu direvisi kembali baik dari segi konten dan konteks. Secara keseluruhan dari analisis data diperoleh bahwa instrument assesmen literasi kimia yang dirancang "valid" dengan nilai rata-rata V yaitu 0,85 . Oleh karena itu instrument assesmen literasi kimia yang dirancang dikatakan bahwa sudah mencerminkan keseluruhan konteks maupun konten.

\section{SIMPULAN}

Berdasarkan penelitian yang telah dilakukan, disimpulkan bahwa secara keseluruhan assesmen literasi kimia pada meteri laju reaksi rmemiliki validitas konten yang "valid" dengan nilai 0,85 . Sedangkan untuk item butir soal, dimana 9 soal pada kategori "valid" dan 4 soal pada kategori "sedang”.

\section{REFERENSI}

1. Permendikbud Nomor 23 Tahun 2006 tentang standar penilaian pendidikan.

2. Yusuf, Muri. 2015. Asesmen dan Evaluasi Pendidikan: Pilar Penyedia Informasi dan Kegiatan Pengendalian Mutu Pendidikan Edisi Pertama. PT Fajar Interpratama Mandiri: Jakarta.

3. Firman, H. 2007. Analisis Literasi Sains Berdasarkan Hasil PISA Nasional Tahun 2006. Jakarta: Pusat Penilaian Pendidikan Balitbang Depdiknas.

4. Hidayati dan Julianto. 2018. Penerapan Literasi Sains dalam Pembelajaran IPA di Sekolah Dasar untuk Meningkatkan Kemampuan Berfikir Kritis Siswa dalam Memecahkan Masalah. ISBN 978-602-6483-63-8. Seminar Nasional Pendidikan Banjarmasin, 24 Maret 2018.

5. Haristy, D. R., Enawaty, E., dan Lestari, I. 2013. Pembelajaran Berbasis Literasi Sains Pada Materi Larutan Elektrolit dan Non Elektrolit di SMA Negeri 1 Pontianak. Jurnal Pendidikan dan Pembelajaran Khatulistiwa. Vol 2, No 12.

6. Prastiwi. M. N. B., Rahmah, N., Khayati, N., Utami, D. P., Primastuti, M., dan Majid, A. M. 2017. Studi Kemampuan Literasi Kimia Peserta Didik Pada Materi Elektrokimia. Prosiding Seminar Nasional Kimia UNY 2017. Sinergi Penelitian dan Pembelajaran untuk Mendukung Pengembangan Literasi Kimia pada Era Global.

7. Shwartz, Y., Ben-Zvi, R., dan Hofdtein, A. 2006.The Use of Scientific Literacy Taxonomy for Assessing the Development of Chemical Literacy Among High-School Students. Chemistry education research and practice, 2006, 7, (4), 203-225.

8. Azwar, Saifuddin. 2012. Reliabilitas dan Validitas. Yogyakarta: Pustaka Pelajar.

9. Nugroho \& Ruwanto. 2017. Pengembangan Media Pembelajaran Fisika Berbasis Media Sosial Instagram Sebagai Sumber Belajar Mandiri Untuk Meningkatkan Motivasi Dan Prestasi Belajar Fisika Siswa Kelas XI SMA. Jurnal Pendidikan Fisika Nomor 6, Volume 6.

10. Duit, R., Gropengierber, H., Kattmann, U., Komorek, M., Parchmann, I. 2012. The Model of Educational Reconstruction - A Framework for improving Teaching and Learning Science. Science Research and Practice in Europe: Retrospective and Prospective, 13-37.

11. Yusmaita, E. 2013. Konstruksi Bahan Ajar Sel Volta Berbasis Green Chemistry Education Untuk Membangun Literasi Sains Siswa. 
Edukimia $\cdot 2019 \cdot$ Vol. 1, No. 3

Universitas Pendidikan Indonesia: (Tesis) tidak diterbitkan.

12. Matondang, Zulkifli. 2009. Validitas dan Reliabilitas Suatu Instrumen Penelitian. Jurnal Tabularasa PPS Unimed. Vol.6 No.1. 